\title{
A társadalmi nem összefüggései a krónikus testi betegségek kialakulásával és lefolyásával
}

\author{
NAGY TÜNDE* - TIRINGER ISTVÁN - KÁLLAI JÁNOS
}

Pécsi Tudományegyetem, Általános Orvostudományi Kar, Magatartástudományi Intézet

(Beérkezett: 2016. január 27.; elfogadva: 2016. április 27.)

\begin{abstract}
Tanulmányunkban a gender-medicina egyik központi témájával kapcsolatos kutatásokat tekintjük át: a nemi szerepek és az egészség kapcsolatát, valamint a nemi szerephez kapcsolódó személyiségvonások hatását a krónikus betegségekhez történő alkalmazkodásra. Áttekintjük továbbá az alkalmazkodásban szerepet játszó megküzdési módok és társas támogatás nemi különbségeit is. A nemi szerepek és az egészség kapcsolatában közvetlen módon az egészségmagatartás, s az énképre gyakorolt hatás révén - közvetetten - a szocializációs folyamatoknak van szerepe. A krónikus betegséghez történő alkalmazkodásban jelentős nemi különbségek tapasztalhatók, amelyeket kevésbé a biológiai nem, mint inkább a nemi szerephez kötött személyiségvonások magyaráznak. A tevékenységorientáltság (agency) és a kapcsolatorientáltság (communion), valamint ezek szélsőséges formái, a túlzott tevékenységorientáltság (unmitigated agency) és túlzott kapcsolatorientáltság (unmitigated communion) jelentősen eltéró hatással van az egészségmagatartásra, a társas kapcsolatokra és a betegségekhez történő alkalmazkodásra. Míg a tevékenységorientáltság (T) összefügg a kedvező egészségmagatartással, a kapcsolatorientáltság (K) a támogató kapcsolatokkal, addig e két személyiségvonás túlzott formái kedvezőtlen gyógyulási esélyekkel, rosszabb mentális és fizikai alkalmazkodással és a betegséget követó distresszel mutatnak kapcsolatot.
\end{abstract}

Kulcsszavak: nemi szerepek, nemi szerephez kapcsolódó személyiségvonások, egészség, alkalmazkodás krónikus betegségekhez

Az egészség-betegség témájával foglalkozó kutatásokban az elmúlt években egyre hangsúlyosabbá vált a nemi különbségek vizsgálata. Az úgynevezett gender-medicina által feltárt adatok rámutattak arra, hogy a tünetek megjelenése, mintázata, a betegségre adott érzelmi és viselkedéses válasz, valamint a betegség kognitív reprezentációja jelentős nemi különbségeket mutat. Számos kutatás megerósíti, hogy a mindennapi orvosi gyakorlatban a nói és férfi betegek kezelése időnként jelentősen eltér egymástól (Hwang \& Danoff-Burg, 2010).

\footnotetext{
* Levelezó szerzó: Nagy Tünde, Pécsi Tudományegyetem, Általános Orvostudományi Kar, Magatartástudományi Intézet, 7624 Pécs, Szigeti út 12. E-mail: tunde.nagy@aok.pte.hu
} 
A kérdéssel foglalkozó kutatások elkülönítik a biológiai és a társadalmi nemet (gender), ugyanakkor számos kutatásban ez a két fogalom még összemosódik. Az orvostudománynak szembe kell nézni azzal a ténnyel, hogy a szocializáció során kialakított nemi szerep és a biológiai nem egymásra kölcsönösen hatva befolyásolják a betegségek kialakulását és határozzák meg a betegségre adott reakciókat, a nehézségekkel való megküzdés módját és az orvossal történő együttmúködés jellegét (Zwicker \& DeLongis, 2010).

A nemi szerepekból adódó különbségek a legmarkánsabban a mortalitási és morbiditási adatokban érhetők tetten. A férfiak társadalmi-gazdasági pozíciói még a fejlett, nyugati országokban is kedvezőbbek, mint a nóké, életkilátásaik a nőkhöz képest azonban kedvezőtlenebbek. A „nemek közötti szakadékként" (gender gap) ismert jelenséget mutatja, hogy Európában a nők átlagosan 5 évvel, Magyarországon majdnem 7 évvel élnek tovább, mint a férfiak. ${ }^{1} \mathrm{~A}$ férfi mortalitás szinte a teljes életút során megközelíti vagy meghaladja a női halandóság kétszeresét. ${ }^{2}$ Az európai átlagnál kisebb gender gap a skandináv országokban és néhány dél-európai országban figyelhetó meg. Várható élettartam tekintetében az átlagnál nagyobb a nemek közti szakadék a balti államokban és Kelet-Közép-Európában, többek között Magyarországon is (Kopp, 2007; Todorowa, 2011).

A Világgazdasági Fórum Global Gender Gap Indexe $\mathrm{e}^{3}$ - amelynek legfrissebb jelentésében Magyarország a korántsem előkelő 93. helyezést érte el a különböző erőforrásokhoz való hozzáférést és azok nemek közti eloszlását méri. Ezek az oktatásban, a munkaerőpiacon, a politikai életben való részvételben és az egészségügyben érhetők tetten. A nők hátrányos megkülönböztetése az egészségügyi szolgáltatásokhoz való hozzáférésben a rehabilitációs programokban (Anderson, 2004) és a klinikai kutatásokban való alacsonyabb részvételben, és sok esetben az egészségügyi személyzet diszkriminatív attitúdjében is megfigyelhető (Doyal, 2001).

\section{Az egészség és a betegségek nemi különbségei}

A várható élettartamban megfigyelhető különbségeket elemző pszichoszociális elméletek feltételezik, hogy a szocializáció során kialakult nemi szerepek az egészség- és betegségmagatartáson keresztül befolyásolják az életkilátásokat.

\footnotetext{
1 http://ec.europa.eu/eurostat/statisticsexplained/index.php/Mortality_and_life_expectancy_ statistics

2 www.ksh.hu/docs/hun/xftp/idoszaki/nepmozg/nepmoz14

3 https://www.weforum.org/reports/global-gender-gap-report-2015
} 
A nemi különbségek megértéséhez számba kell vennünk az életvitellel összefüggő attitüdök, az egyéni viselkedés (életmód, egészségmagatartás), valamint az egészség és az élettartam kapcsolatát, amelyek az egészségi állapot legfontosabb meghatározói egyéni és közösségi szinten egyaránt (Pikó, 2010). E tekintetben a legfeltúnőbb jelenség, hogy a férfi nemi szerep, illetve a férfiként történő szocializáció sok szempontból az életkilátásokat befolyásoló egészségi kockázati tényezőnek tekinthető. Bár a témával sok kutatás foglalkozott, egyelőre nincs egyértelmú válasz arra, hogy mi hozza létre az átlagos élettartamban megfigyelhetó nemi különbségeket.

A betegség vagy sérülés kialakulásának kockázatát növelő tényezőket rizikófaktoroknak nevezzük, amelynek lényeges eleme a kockázatnöveló magatartás. Az egészség megőrzését és helyreállítását szolgáló tényezőket egészségmagatartásként foglalhatjuk össze. Ezeket a negatív és pozitív tényezőket a nemi szerepekhez kötődő viselkedés különböző összetevői, kulturális hatások, szokások, gondolkodásmód, életfilozófia befolyásolják (Matarazzo, 1984).

A fejlett országokban bizonyos rizikófaktorok nemi eloszlása egységes képet mutat. A férfiak többet dohányoznak, alkohol- és drogfogyasztásuk magasabb, gyakrabban szenvednek balesetet. A nők nagyobb gondot fordítanak az egészségre és a betegségek megelőzésére, de emellett kevesebbet mozognak (Lee, 2010). A férfiak egészségmagatartását nagyban befolyásolja az ideális férfikép megvalósítására való törekvés. A sztereotípiákat követóen a maszkulin ember erős, keményen dolgozik, nem törődik a saját egészségével, és így szerez előnyt másokkal szemben, miközben nyilvánvalóan árt magának. A tradicionális férfi szerepelvárásból eredő stressz, rossz általános egészségi állapot és közérzet az egészséget romboló dohányzással szoros összefüggést mutat (Susánszky, Susánszky, \& Kopp, 2009). Férfiaknál - főleg az idősebb korosztályban - az egészségi állapottal való törődés férfiatlan viselkedésnek számít, az egészséges életmód helyett inkább a kockázati magatartásokat preferálják (Courtenay, 2000; idézi Susánszky és mtsai, 2009).

Ennek ellenkezője a hagyományos női beállítódás, amely törődik a saját és a családja egészségével, kockázatkerülő, és jól informált az egészséggel, a helyes táplálkozással és a jólléttel kapcsolatban, viszont nem sokat tesz a fizikai képességeinek növelése érdekében. Ennek a hagyományos felfogásnak az az ára, hogy a nők többsége nem keres lehetőséget a rendszeres testedzésre (Choi, 2000), a rendelkezésükre álló kevesebb szabadidó is közre játszhat azonban a rendszeres fizikai aktivitás alacsony szintjében (Pongráczné, 2005).

A gender-medicina egyik értékes kutatása Luy (2002) kolostorvizsgálata. Apácák és szerzetesek élettartamának vizsgálata azt mutatta, hogy az életkilátások nemi különbsége a kolostorban élők között az átlagnépességhez 
képest lényegesen kisebb, s az élettartamban az apácák javára van kismértékú szignifikáns különbség. Elsősorban a szerzetesek várható élettartama lényegesen magasabb (közel 4 évvel), mint az átlagos férfiaké, az apácák és az átlagos nők közel hasonló ideig élnek. A jelenség magyarázataként feltételezhető, hogy az apácák és szerzetesek életmódja nagymértékben hasonló, a kolostori életmód és a vallásos életvitel mellett a hagyományos nemi szerepek hatása kevésbé érvényesül. Az életkilátások nemi különbségeit magyarázó elméletek értékelése kapcsán meg kell azonban jegyezni, hogy a monokauzális modellek nem kielégítőek.

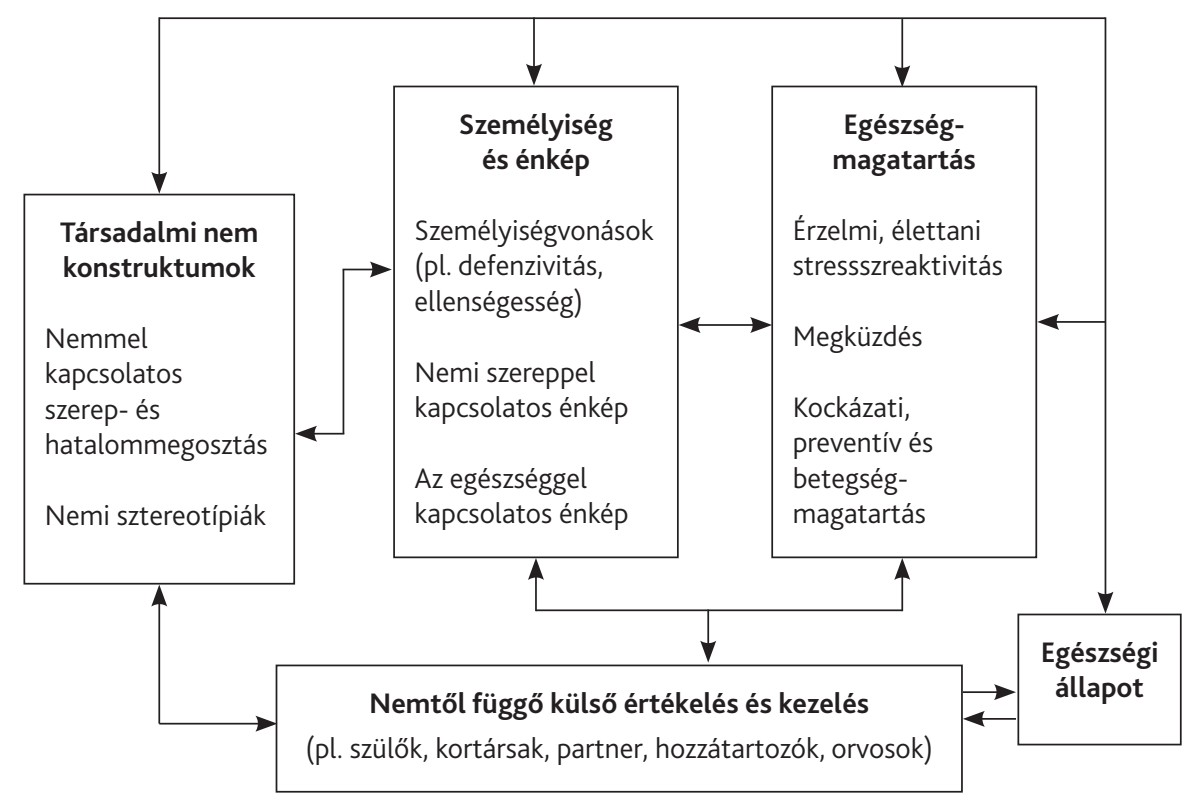

1. ábra. A nemi szerepek és az egészség kapcsolata

(Sieverding, 2009, 132. o. nyomán)

A nemekkel kapcsolatos társadalmi kép, a nemi szerepek és attitúdök elvárásokként múködnek, amelyek viszonyítási pontként szolgálnak a nők és a férfiak számára. Sieverding (2009) heurisztikus modellje (1. ábra) több utat valószínúsít, amelyek révén a társadalmi gender-konstruktumok - pszichológiai változók közvetítésével - befolyásolják az egyén egészségmagatartását és egészségét. Deaux és Lafrance (1998) munkái gender-konstruktumnak tekintik a társadalmi pozíciók és szerepek nemektől függő felosztását, valamint a nemi sztereotípiákat - az elvárt és megfelelőnek gondolt viselkedésmódokat és személyes tulajdonságokat férfiak és nők esetében. Ezek a gender-konstruktumok az egyént közvetlenül, másrészt kapcsolati-társadalmi környezete viszonyulásain keresztül befolyásolják. 
A nemi szerepek és sztereotípiák közvetlenül hatnak az egészségmagatartásra, többek közt az olyan kockázati tényezókre, mint a dohányzás és az alkoholfogyasztás. Különösen akkor, ha ezekkel kapcsolatban nemtól függő „elvárások” vagy „tiltások” múködnek. Például férfitársaságokban sokszor érezhetó elvárás a jelentós alkoholfogyasztás. Bizonyos férfi szubkultúrákra jellemző a férfiasság demonstrálása kockázatvállaló viselkedéssel, például az autóvezetésben (Courtenay, 2000). A múlt század közepéig a nói dohányzás társadalmi elítélése miatt a nők nyilvánosan nem dohányoztak. További példa az evészavarok és a természetellenes karcsúsági ideál kapcsolata nők esetében.

Sieverding (2009) feltételezi, hogy a nemi szerepek és sztereotípiák közvetetten is hatnak, a szocializáció, a nevelés és a társas interakciók személyiségfejlódésre gyakorolt hatása révén; a sztereotípiák beépülnek az énképbe, és befolyásolják a férfiak és a nők egészségfelfogását. Az egyéni sajátosságok különböző közvetítő utakon keresztül hathatnak az egészségre. Az egyik út az egészségmagatartás, a kockázatot jelentő szokások, az egészséges életvitel és a stresszel történő megküzdés. Egy másik út az érzelmi és élettani stressz-reaktivitáson keresztül vezethet. A modell (Sieverding, 2009) feltételezi, hogy az egészségmagatartás a fontos kapcsolati személyek magatartásától is függ (kortársak, partner és kezelőorvosok).

\section{A nemi szerepek jelentósége}

A férfias és a nőies viselkedésformák részben biológiailag meghatározottak (Bereczkei, 2003). A férfiasság és nóiesség másrészt társadalmi konstruktumok is, amelyek idővel, különböző korszakokhoz és kultúrákhoz kapcsolódóan tartalmukban jelentős változásokat és különbségeket mutatnak. A férfiasság és nőiesség fogalmába különböző szempontok sorolhatók, például testi sajátosságok, szexuális preferencia, viselkedésmód, beszédmód és személyiségsajátosságok. A mindennapok során a férfiak és a nők jellemző törekvése, hogy nemi szerepüknek megfelelően formálják gondolkodásukat és viselkedésüket, egyfajta társadalmi kontroll múködik a férfias és nőies viselkedéssel kapcsolatban. Tanulmányunkban a továbbiakban nem foglalkozunk a nemi szerepek normativitásával, csupán azzal, hogy hogyan hatnak ezek a társadalmi elvárások az egyén énképére, illetve ennek révén pszichológiai alkalmazkodó képességére és jóllétére. Utóbbi kérdést az elmúlt évtizedekben számos kutatás vizsgálta, amelyek a nemi szerephez kapcsolódó énkép (gender role self-concept) hatásaira irányultak (Bem, 1974; Spence, Helmreich, \& Stapp, 1974). A vizsgálatok alapján körvonalazható egy tipikus férfias és nóies személyiségmintázat, amely a szociálisan elvárt férfi és női sajátosságokat tükrözi. A sztereotip női viselkedés expresszív (feminin) 
sajátosságokkal jellemezhetó: passzív, alkalmazkodó, engedékeny, óvatos, szorongó, harmóniára törekvó, függő, emocionális, kevésbé magabiztos, illetve kapcsolatorientált. Az instrumentalitás (maszkulinitás) sztereotip férfi jellemzőket foglal magában: aktív, agresszív, racionális, büszke, célra törekvő, versengő, független, magabiztos, kockáztató, a döntésekben domináns (Stake \& Eisele, 2010).

A koncepció előnye, hogy a maszkulin (instrumentális) és a feminin (expresszív) sajátosságokat a biológiai nemtől függetlenül vizsgálja. Nem minden nő viselkedik szükségszerúen nóiesen, és nem minden férfi férfiasan. A feminin és maszkulin vonások olyan sajátosságok, amelyeket társadalmi normák alapján nőknek és férfiaknak tulajdonítunk, emellett azonban a férfiak és a nők énképükbe, illetve a saját nemükről alkotott képbe integrálják őket, s azok alkotóelemeivé válnak.

A kutatások az 1970-es évekig abból indultak ki, hogy a maszkulinitás és a femininitás egymást kizáró kategóriák, amelyek egy zárt női és férfi nemi identitás részét képezik. Késóbb a kutatások a maszkulin és feminin skálák mellett két további típussal egészültek ki, amelyek vagy mind az expreszszív, mind az instrumentális sajátosságok magas szintjén alapulnak (androgün típus), vagy mindkét skála alacsony értékeivel jellemezhetők (nem differenciált típus) (Bem, 1974). A kutatások eredményei alapján nem tartható az ún. kongruencia hipotézis, amely értelmében azon személyek lelki egészségmutatói a legjobbak, akiknek sajátosságai leginkább illeszkednek biológiai nemükhöz - tehát a maszkulin férfiaké és a feminin nőké. A tradicionális nemi szerepekhez igazodókhoz képest (férfias férfiak, nőies nők), akiknek viselkedését a merevebb és szúkebb szerepek korlátozzák, az androgün személyiségek rugalmasabban tudnak alkalmazkodni, tudnak gondoskodók és függetlenek is lenni, ahogy az aktuális helyzet megkívánja. Egy kutatásban, ahol a meddóséghez való alkalmazkodást és a nemi szerepbeállítódásokat vizsgálták, azok a párok számoltak be a legjobb életminőségről, akik a maszkulin és a feminin skálákon egyaránt magas értékeket értek el (Cserepes és mtsai, 2014). Bem hipotézisét azonban - miszerint az androgünök lelkileg egészségesebbek lennének - évtizedek kutatási eredményei sem tudták igazolni (Weiten, Dunn, \& Hammer, 2015).

Az egészségmagatartás nemi szerepekkel összefüggő különbségei kulturális háttérrel is magyarázhatók. Magyarországon a nemi szerepekkel kapcsolatban a tradicionális felfogás meghatározó, ami hosszmetszetileg is következetesen megfigyelhető. Az 1974-es adatokhoz képest az ezredfordulóra lényegi változás nem történt e tekintetben (Pongráczné, 2005). Egy friss országos reprezentatív közvélemény-kutatás szerint ${ }^{4}$ a hagyományos csa-

4 http://ipsos.hu/hu/news/megsem-mindegyikojuk-cipoje-illik-ra-ugyanarra-a-kaptafara 
ládmodell még mindig tartja magát. A válaszadók legnagyobb része (44\%) konzervatív nézeteket vall a férfi-női szerepekről, a munka és magánélet egyensúlyának kivitelezhetőségéről. Nemzetközi összehasonlító vizsgálatok adatai szerint Magyarországon az európai, dél-amerikai, ázsiai populációkkal összevetve a szélsőséges maszkulin, illetve a szélsőséges feminin ideálok az elfogadottak. Kiegyenlített maszkulin-feminin szerepek leginkább a skandináv országok társadalmaira jellemzőek (Arrindell és mtsai, 2003). Mindemellett meg kell említenünk, hogy a betegségkockázatnak tekinthető szorongásosság szintén a markánsan maszkulin kultúrákban detektálható, többek között Magyarországon is, ugyanakkor a kiegyensúlyozottabb nemi szereprepertoárral rendelkező kultúrákban élő közösségekre a kollaboráció, a demokratikus együttélési formák mellett alacsonyabb szorongásszint jellemző (Arrindell és mtsai, 2004).

Több vizsgálat foglalkozott az egészségmagatartás és a férfias-nóies énkép kapcsolatával. A testi állapotról szóló önbeszámolók és a morbiditási, mortalitási adatok összevetése azt mutatja, hogy a férfiak kevesebbet panaszkodnak, egészségállapotuk negatívumait nem hangsúlyozzák, a pozitívumokat pedig túlértékelik (Helgeson, 2003a; Sieverding, 2005). Lewis Terman 60 évet átölelő longitudinális vizsgálati anyagának újraértékelése során (amelyben 654 férfi és 200 nő vett részt) Lippa és munkatársai (Lippa, Martin, \& Friedman, 2000) megállapították, hogy a maszkulin típusú foglakozások iránt érdeklődő személyek mortalitása a biológiai nemüktől független. Ez az összefüggés minden vizsgált korcsoportban kimutatható volt. Azaz, a maszkulin tevékenység preferenciája nemtól függetlenül rontja az életkilátásokat. Egy másik vizsgálatban (Hunt, Lewars, Emsli, \& Batty, 2007), amelyben 1551 férfi és nő vett részt, azt találták, hogy a nemi szereppel kapcsolatos énkép a koszorúér-halálozás független előrejelzője volt. A vizsgált populációban nem elsősorban a maszkulin személyek kockázata volt magasabb, sokkal inkább a feminin személyiségvonások protektív hatása látszott, különösen a férfiak esetében.

Tanulmányunkban a továbbiakban a krónikus betegségek és a nemi szerepekből adódó sajátosságok összefüggéseit vizsgáljuk meg.

\section{Nemi szerepek, egészségkockázatok és krónikus betegségek}

A krónikus betegséghez történő alkalmazkodás kérdését a nemi szerepek perspektívájából körüljárva úgy túnik, hogy mind a hagyományos férfi, mind a hagyományos női nemi szerep megkönnyítheti, de meg is nehezítheti ezt a folyamatot. 
A férfi nemi szerep

A hagyományosan férfias viselkedés olyan jellemzői, mint a függetlenség és önuralom megnehezítheti az ilyen egyénnek a másoktól való segítségkérést, vagy a függóség elviselését. Ez fóleg egy krónikus betegség esetében lehet probléma, ami a gyengeség és a kiszolgáltatottság érzését keltheti. A beteg állapotának romlása és a teljesítménycsökkenés pedig a kenyérkereső szerepet ingathatja meg. A hagyományos férfi nemi szerep úgy is akadályozhatja az alkalmazkodást, hogy csökkenti a beteg compliance-ét. Például koszorúér-betegség esetében az orvos szigorú diétát, rendszeres testmozgást és a kockázatot növelő szokások elhagyását írja elő, ami a betegben a szabadság elvesztésétól való félelmet és a kontrollvesztés érzését keltheti (Helgeson, 2012).

A férfi nemi szerep alkalmazkodást megnehezítő további sajátossága az érzelmek kifejezésének nehézsége. A tradicionális férfi szerep azt követeli meg a férfitól, hogy tartsa rejtve mások elől az érzéseit és a gyengeségeit, $\mathrm{s}$ ha beteg, ne panaszkodjon. Ennek az lesz a következménye, hogy a férfiasan viselkedő beteg megfosztja magát a kellő és szükséges segítségtől és támogatástól.

A férfi nemi szerep másik oldala viszont jelentősen hozzájárulhat az alkalmazkodás sikeréhez, ha a betegséget úgy értelmezzük, mint egy megoldásra váró problémát. Amennyiben vannak olyan lehetőségek, amelyek egyértelmúen megoldják, vagy legalábbis kedvezóen befolyásolják a problémát, akkor a férfiak azt vállalják. Ilyen „megoldás” a férfiak számára a testmozgás. A férfi szívbetegek gyakrabban végeznek testmozgást, mint a nók, mert ez kongruens a nemi szerepükkel. Amennyiben a probléma befolyásolható, a kontrollra törekvő viselkedés adaptív, mert segíti az alkalmazkodást. Így a férfi nemi szerep sikeres és problémás alkalmazkodáshoz is köthető, az előbbi esetben a nemi szerep segíti ezt a folyamatot, az utóbbi esetben a betegség veszélyeztetheti a férfiasság bizonyos aspektusait és nehezebb felépülést tesz lehetóvé (Helgeson, 2012).

\section{A nôi nemi szerep}

A női nemi szerep alkalmazkodásban szerepet játszó jellemvonása a gondozói magatartás. Ha az egyén identitásának központi jellemzője a gondozói szerep, és ha az adott betegség ezt a szerepet korlátozza, akkor az alkalmazkodás nem lesz sikeres, mert az egyén el fogja hanyagolni a saját egészségét. A támogatás elfogadása és a segítségnyújtás konfliktusa különösen azoknál az egyéneknél élesedik ki, akiknél a gondozói szerep a legfontosabb. A női nemi szerep más jellemzői viszont nagyban hozzásegíthetik az egyént a sikeres alkalmazkodáshoz. A női nemi szerep megengedi a segítségkérést és a bizalmat mások felé, akiktől társas támogatást várhat, ami nagyban hozzájárulhat a krónikus betegséghez való adaptív alkalmazkodáshoz (Helgeson, 2012). 
A krónikus betegségben megfigyelt alkalmazkodás nemi különbségeinek egyik magyarázata, hogy a férfiak és a nők eltérően szocializálódnak, a férfiak az önérvényesítés felé, a nők a közösségek teremtése irányába mutatnak nagyobb motivációt (Weiten és mtsai, 2015).

\section{Krónikus betegségekhez történó alkalmazkodás nemi különbségei}

A magyar társadalomban az európai átlaghoz hasonlóan egyre magasabb az időskorúak aránya: 2015. január 1-jén 100 gyermekre 124 időskorú lakos jutott. ${ }^{5} \mathrm{Az}$ idősek számának növekedése együtt jár a krónikus betegségek növekvő prevalenciájával. A krónikus betegek életesélyeinek javulása a biológiai, pszichológiai és szociális ellátásra fordított fokozottabb figyelemtől várható. A krónikus betegség jelentéstartalma bővül. A betegség biológiai lefolyásának leírásán túl magába foglalja az adott állapottal kapcsolatos élményeket, életvezetési akadályokat, megküzdési és alkalmazkodási módokat és a betegségre vonatkozó szociális és egyéni reprezentációkat (Stanton \& Revenson, 2007). A betegséghez való alkalmazkodásba beletartozik a diagnózisra adott reakció, úgyis, mint a diagnózist követő adaptációs képesség és a fizikai funkcionalitás mértéke. A krónikus betegséghez való alkalmazkodás egy dinamikus folyamat, ami változhat és fejlődhet az idővel és az élet összes területére hatással van (Stanton, Collins, \& Sworowski, 2001).

A nőbetegek általában rosszabb életminőségről számolnak be. Ennek okai sokrétúek: a nók tovább élnek, és több betegségtől szenvednek. Mindemellett kulturálisan jobban megengedett egy nőnek, hogy hangot adjon az aggodalmainak, a szorongásainak, míg a férfiaktól az elvárt viselkedés a sérülékenységük elrejtése vagy a betegség sztoikus túrése (Kaplan, Anderson, \& Wingard, 1991), a látszólag problémamentes életvezetés fenntartása, és a betegségből származó akadályok felszámolása (Addis \& Mahalik, 2003; Smith \& Gallo, 2001). A stressz percepiójában és megélésében, valamint a társas támogatás minőségében is élesen különválik a két nem (Vaccarino, 2015). A megküzdési stílusban is megmutatkoznak a nemi különbségek, amelyek legfőképpen a megélt stresszor típusától függenek. Taylor és munkatársai (2000) tanulmányából kiderül, hogy a nők számára az interperszonális konfliktusok a leggyakoribb és legnagyobb stresszt jelentő helyzetek. A nők a férfiakhoz mérve nagyobb figyelmet fordítanak a megfelelő szociális háló fenntartására. Nemcsak a saját életük, hanem a körülöttük élő fontos személyek életeseményei is stresszforrások számukra. A partnerkapcso-

5 www.ksh.hu/docs/hun/xftp/idoszaki/nepmozg/nepmoz14.pdf 
lati zavarok csökkenthetik a jóllétet, növelik az elszigeteltség érzését és a reménytelenséget (Coyne \& DeLongis, 1986). A rosszul múködő házasságban mindkét fél, de elsósorban a nó egészségi állapota rosszabb (KiecoltGlaser \& Newton, 2001): házassági konfliktus esetében a nők rosszabb szívés érrendszeri, immun- és endokrinfunkciókat mutatnak, mint a férfiak. Orth-Gomér és munkatársainak (2000) 5 éves követéses vizsgálatából az derül ki, hogy a házastársi stressz a kardiovaszkuláris betegségben szenvedó nőknél erőteljesebben rontotta a betegség prognózisát, mint a munkahelyi stressz. A jó házastársi kapcsolat ugyanakkor jó egészségi állapottal (Balog, Székely, Szabó, \& Kopp, 2006; Traa, De Vries, Bodenmann, \& Den Oudsten, 2015), kevesebb depresszív tünettel (Rottmann és mtsai, 2015) és magasabb szintú fizikai jólléttel (Bodenmann, Pihet, \& Kayser, 2006) jár együtt. Egy metaanalízisben (Hagedoorn, Sanderman, Bolks, Tuinstra, \& Coyne, 2008) a szerzők a gender és a beteg-házastárs szerep közti kapcsolatot vizsgálták olyan pároknál, ahol az egyik fél rákos volt. Azt találták, hogy a társadalmi nem jobb prediktora volt a distressznek, mint a beteg-házastárs státusz. Ez annyit jelent, hogy a nők jelentősebb stresszről számoltak be függetlenül attól, hogy ők voltak-e a betegek vagy a partnerük. A nők nemcsak társként, hanem betegként is hajlamosabbak a "védő hárító" (protective buffering) szerepre (Badr, 2004), amit a betegséggel kapcsolatos aggodalmak és félelmek tagadása, elrejtése és a nézeteltérések elkerülése érdekében való engedékenység jellemez (Hinnen, Hagedoorn, Ranchor, \& Sanderman, 2008; Schokker és mtsai 2010), és ami nagyobb distresszel jár együtt (Manne és mtsai, 2007).

A társas támogatás kulcsfontosságú forrása a stesszkezelésnek és az adaptív megküzdési folyamatnak, és nyilvánvalóan enyhíti a stressz negatív hatását, valamint jobb egészséghez vezet (Taylor, 2007). A nők stresszhelyzetben gyakrabban keresnek társas támogatást, mint a férfiak, gyakrabban használják a szociális kapcsolataikat megküzdési erőforrásként, gyakrabban is nyújtanak támogatást másoknak, és a nők által nyújtott segítség előnyösebb a támogatásra szorulók számára, mint a férfiaktól kapott (Taylor, 2007). A nők e speciális „hangoltsága” teszi lehetővé, hogy elegendő érzelmi támogatást tudnak nyújtani beteg férjüknek. Míg ellenkező esetben, amikor a nő a beteg, sokszor úr tátong a nők érzelmi szükséglete és a férjüktől kapott csekély érzelmi támogatás között (Goldzweig és mtsai, 2009; Verhofstadt, Buysse, \& Ickes, 2007). Nem meglepő, hogy mind a nők, mind a férfiak gyakrabban fordulnak támogatásért nőkhöz, a házasságban élő férfiak leggyakrabban a feleségüktől kérnek támogatást, a férjezett asszonyok pedig más nőktől (Taylor és mtsai, 2000). Egy vizsgálatban több mint 10000 megkérdezett közül a férfiak majdnem fele vallotta azt, hogy a feleségükhöz fordulnak elsőként, ha támogatásra van szükségük, míg ugyanebben a populációban a nők csak 25\%-ának volt a férje az elsődleges támogatója (Orth-Gomér, 2015). 
A nők az identitásukat az interperszonális kapcsolataik mentén definiálják, a férfiak ugyanakkor saját identitásukat az eró és a függetlenség mentén fogalmazzák meg. Az alapértékeket veszélyeztető krónikus betegségekre tehát a nők és a férfiak - nemi szerepükből adódóan - markánsan különböző módon reagálnak.

\section{A nemi szerephez kapcsolódó személyiségvonások és az egészségi állapot}

Az elmúlt években egyre növekvő figyelmet kaptak a szakirodalomban az olyan kutatások, amelyek a nemi szerephez kapcsolódó személyiségvonások, az agency és a communion, valamint az egészség kapcsolatát vizsgálták. Az agency olyan személyiségjegyet jelent, mint az öntudat, individualizáció, ami a szeparációt hangsúlyozva magabiztosságra és önbátorításra fokuszál. A communionvonás pedig olyan személyiségjegyekkel kapcsolódik, amelyek előterében a közösségteremtő kooperáció, gondoskodás, empátia és kötődés áll. A magas agency szintjével jellemezhető személyek az egyéni létezést különálló egyediként, a communionnal jellemezhető személyek pedig a saját létezésüket egy nagyobb organizmus részeként élik meg. Az agency fordításaként a magyar nyelvú szakirodalomban az ágencia fogalma terjedt el (Antal Bacsó, 2010), ami személyes hatóerőt, szabad akaratot fejez ki, egyfajta tevékeny, önérvényesítő viselkedési stílust. A communion magyarul affiliációként fordul elő a szakirodalomban (Carver \& Scheier, 2006), és jelentésében a befogadást, lelki közösséget, érintkezést és a közösségbe tartozást ragadja meg: egy olyan viselkedést, ahol a kapcsolat, a társas érintkezés önmagában, a saját jogán a cél. Jelen tanulmányban e két személyiségvonást tevékenységorientáltságnak (agency) és kapcsolatorientáltságnak (communion) fordítottuk.

A Bakan (1966) elméletére épülő helgesoni modell (Helgeson, 1994) alapvetése, hogy a férfiak és a nők a szocializációjuk során eltérő viselkedésmintákat és szociális szerepeket vesznek fel, és ezek a különbségek megkönnyíthetik, de alá is áshatják érzelmi és fizikai jóllétüket. Nevezetesen, a férfiak gyakrabban tanulnak meg tevékenységorientáltságra jellemző személyiségjegyeket (énre irányult fókusz, autonómia), míg a nők a kapcsolatorientáltságra irányuló jellemzőkre fogékonyak.

A tevékenységorientáltság egy olyan széles konstruktum, ami az egészséges énközpontúságot fejezi ki. Szoros kapcsolatban van a fizikai és mentális jóléttel, valamint a magas önbecsüléssel, de nincs közvetlen hatása a kapcsolati viszonyokra. A kapcsolatorientáltság pedig egy olyan széles konstruktum, ami ugyanakkor a mások felé irányuló egészséges kapcsolati viszonyra utal. Nincs közvetlen kapcsolatban a mentális jóléttel vagy az 
önbecsüléssel, ám szoros kapcsolatban van a társas támogatással. A lelki egészség feltételezi mind a tevékenységorientált, mind a kapcsolatorientált viszonyulást, amelyek kiegészíthetik egymást (Helgeson, 1994; Helgeson \& Fritz, 1999). Az optimális jólléthez mindkét személyiségjegy kiegyensúlyozott jelenlétére szükség van. A markáns hangsúlyeltolódásoknak gyakran egészségi következményei vannak.

A tevékenységorientáltságnak egy szúk szelete a túlzott tevékenységorientáltság (TT, angolul: unmitigated agency), ami a férfiasságnak a társadalmilag nem elfogadott aspektusait ragadja meg. Számos egészségre ártalmas következménnyel jár, amelyek az egyénre és a társadalomra egyaránt veszélyesek: arrogancia, cinizmus, kapzsiság, ellenségesség, másokról alkotott negatív kép, ellenségesség és egy olyan önmaga felé irányított fókusz, ami kizár másokat (Helgeson 1994; Helgeson \& Fritz, 1999; 2000). A férfiaknál a TT magasabb arányban fordul elő, mint a nőknél, pozitívan korrelál a tevékenységorientáltsággal, és negatívan a kapcsolatorientáltsággal. ${ }^{6}$

A túlzott kapcsolatorientáltság (TK, angolul: unmitigated communion) esetében hasonló dinamika mutatkozik, és a nőiesség társadalmilag nem elfogadott aspektusait foglalja magába. A túlzottan kapcsolatorientált egyént egy olyan, mások felé irányult fókusz jellemzi, ami kizárja az ént. Egyfajta abszolút kapcsolatorientáltság, ami mentes a tevékenységorientáltságtól. A túlzott másikra fokuszáló attitúd negatív következményekkel járhat: túlságosan belebonyolódik mások problémáiba, és mások igényeit a sajátjai elé helyezi, aminek következtében ez utóbbiakat elhanyagolja (Fritz \& Helgeson, 1998; Helgeson \& Fritz, 1998). A TK gyakrabban fordul elő nőknél, pozitívan korrelál a kapcsolatorientáltsággal, mert másokra reflektál, és negatívan korrelál a tevékenységorientáltsággal, mert hiányzik az önmagára irányuló figyelem (Helgeson \& Fritz, 1999).

6 A kapcsolatorientáltság és a tevékenységorientáltság mint a férfiasság és a nőiesség társadalmilag elfogadott aspektusainak mérésére leggyakrabban a Bem Sex Role Inventory-t (BSRI; Bem, 1974) és a Personal Attributes Questionnaire-t (PAQ; Spence és mtsai, 1974) használják. Ez utóbbit egy magyar vizsgálatban használták már (Cserepes, 2015). A túlzott tevékenységorientáltságot az Extended Version of Personal Attribute Questionnaire (EPAQ; Spence, Helmreich \& Holahan, 1979) unmitigated agency alskálája méri. A túlzott kapcsolatorientáltság mérésére Helgeson Revised Unmitigated Communion Scale-jét használhatjuk (Helgeson, 1993; Helgeson \& Fritz, 1998). 


\section{A nemi szerephez kapcsolódó személyiségvonások kapcsolata más személyiségkonstruktumokkal}

A Big Five személyiségvonásokkal összevetve a tevékenységorientáltság (T) az extroverzióval, a lelkiismeretességgel és az érzelmi stabilitással mutat kapcsolatot (Ghaed \& Gallo, 2006; Helgeson \& Fritz, 2000). A túlzott tevékenységorientáltságból (TT) azonban hiányzik a lelkiismeretesség, a barátságosság és az érzelmi stabilitás (Helgeson \& Fritz, 2000). A kapcsolatorientáltság (K) ugyanakkor extroverzióval, lelkiismeretességgel, barátságossággal és mások iránti nyitottsággal jár együtt (Helgeson \& Fritz, 2000). A túlzott kapcsolatorientáltság (TK) nem redukálható a Big Five dimenziókra, mérsékelten korrelál a barátságossággal és az extroverzióval, ami teljes egészében a kapcsolatorientáltsággal való átfedésnek köszönhetó (Helgeson \& Fritz, 1999).

Az interperszonális körbe (Wiggins \& Trappnel, 1996) helyezve a T a domináns, magabiztos, a K pedig a melegszívú és barátságos tengelyen ábrázolódnak (Ghaed \& Gallo, 2006). A TT-t az arrogáns-számító kvadráns írja le a legjobban, amit magas T és alacsony K jellemez. A magas T-t és magas K-t a társaságkedvelö-extrovertált kvadráns jeleníti meg. Az alacsony T-t és alacsony K-t az introvertált és közönyös kvadráns reprezentálja, az alacsony T-t és magas K-t pedig az igénytelen, leleményes kvadráns képviseli (Wiggins \& Broughton, 1985; idézi Helgeson \& Fritz, 1999). Ez utóbbi kvadránshoz lehetne leginkább sorolni a TK-t, bár ez nem ragadja meg jól a TK lényegét és a személyiség korrelátumait tekintve elhelyezésével kapcsolatban nem következetes a kép. A TK esetében a saját igények érvényesítésének hiánya megmutatkozik ugyan, de a mások ügyeibe való túlzott beavatkozás bizonyos fajta kontrolltörekvéseket is tartalmaz. Ezek jelenlétét, az indirekt kontrollt, a vonás alapú kérdőívek nem tudják pontosan megmutatni.

A kötődéselmélet szerint a személynek a kötődésszemély érzelmi elérhetóségével kapcsolatos korai tapasztalatai meghatározzák, hogy késóbbi kapcsolataiban mennyire érzi magát biztonságban, és bízik meg másokban (Bowlby, 1969). Bowlby szerint a gyermek belső mentális „munkamodelleket” építi fel önmagáról, másokról és a másokkal való kapcsolat jellegéról, és később ezeket használja a világgal való viszonyának kialakításában (Carver \& Scheier, 2006). A kötődési stílus tekintetében Bowlby modelljéből kiindulva Bartholomew és Horowitz (1991) a szerethetóség és a megbízhatóság alapján négy kötődési alapformát vázolt fel. Ezek a következők: a biztonságos (én pozitív, a másik is az), aki jól kezeli az intimitást és az autonómiát; az elárasztott (én negatív, a másik pozitív), akinek a kapcsolatok kötik 
le minden mentális kapacitását; az elutasító (én pozitív, a másik negatív), aki elutasítja az intimitást, függésellenes; és a félénk (én negatív, a másik is az), aki fél az intimitástól, szociálisan elkerülő. ${ }^{7}$

Helgeson és Fritz (1998) kutatásában a K és TK viszonyát vizsgálta a kötődési stílusukat illetően. Megállapítása szerint a magas K szintjével jellemezhető egyének más-pozitív kötódési stílusúnak tartják magukat, míg a magas TK szinttel jellemezhető egyének önmagukat én-negatív kötódési stílusúnak sorolták be. Ez utóbbi két kötődési stílusba sorolható egyén Bartholomew és Horowitz (1991) elmélete szerint a másiktól teszi függóvé az önbecsülését, bár az elárasztott stílusba sorolható személy jobb kapcsolatot alakít ki másokkal, mint a félénk egyén.

\section{A nemi szerephez kapcsolódó személyiségvonások szerepe a betegségekhez való alkalmazkodásban: kockázatnöveló és protektív hatások}

Korábban kifejtettük, hogy a krónikus betegségek kialakulásában és lefolyásában elsősorban a túlzottan tevékenységorientált (TT), illetve a túlzottan kapcsolatorientált (TK) vonásoknak van negatív hatása az egészségmagatartásra, a társas kapcsolatokra és a betegségekhez való alkalmazkodásra. A továbbiakban azt tekintjük át, hogy a kutatások alapján a túlzott kapcsolat-, és tevékenységorientáltság milyen módon kapcsolódik különböző betegségek kimenetelével.

Onkológiai betegekkel végzett vizsgálatok eredményei szerint a TK rossz mentális és fizikai funkciókkal társult, 3 hónap távlatában pedig egyre romló funkciókat mutattak azok a betegek, akik alacsony önbecsüléssel, torzult testképpel, kevesebb optimizmussal és a külső kontrollba vetett nagyobb bizalommal rendelkeztek, több társas kapcsolati problémáról, distresszről és a társas támogatás csökkenéséről számoltak be (Helgeson, 2003b; Piro, 2001).

Prosztatarákos férfiak körében a T jó életminóséget jelzett, a TT azonban alacsony életminőséggel társult, aminek jelzói a több zavaró gondolat a betegséggel kapcsolatban, az idő múlásával több depresszív tünet és rosszabb mentális státusz. Ezek oka a csökkent énhatékonyság-érzés és az események feletti kontroll elvesztése (Helgeson, 2004; Helgeson \& Lepore, 1997).

Egy rheumatoid arthritisben (RA) szenvedő betegekkel folytatott vizsgálat tanúsága szerint (Trudeau, Danoff-Burg, Revenson, \& Paget, 2003) a TK betegek mentális és fizikai egészsége rosszabb, nagyobb pszichológiai distresszt élnek át, és alacsonyabb az élettel való elégedettségük. A TT bete-

7 Részletes magyar nyelvư ismertetését lásd Láng (2006) munkájában. 
gek pszichológiai distressz szintje is nagyobb a T betegekéhez mérten, a T jobb fizikai és mentális egészséggel jár együtt. A tanulmány érdekessége, hogy olyan betegséget választ vizsgálódása tárgyául, ami tipikusan „női” betegség - az RA nőknél 2-3-szor gyakrabban fordul elő -, a vizsgált betegek közé mégis bevontak férfiakat, bár jóval kisebb arányban (20\%). A relatív női többség ellenére a TK előfordulási aránya a férfi és a női betegek közt egyenlő volt, ami azzal magyarázható, hogy a vizsgálatba bevont férfiak közt a TK aránya magasabb volt, mint az egészséges egyetemista férfiak esetében (Fritz \& Helgeson, 1998). A férfi betegek közt elóforduló magas TK arányt valószínúleg nem magyarázza a betegségspecifikusság, mert egy ehhez hasonló eredményt találunk Fritz (2000) szívbetegekkel végzett kutatásában is. A szerző a TK egyenlő nemi megoszlását a krónikus betegséggel történő tartós együttéléssel és a - következményesen kialakuló - másoktól való függéssel magyarázza, ami megnövelheti a TK hajlamot az egyénben.

Helgeson (2011) diabéteszes és egészséges kamaszokat vizsgált öt éven keresztül, akik a vizsgálat kezdetén 10-14 éves kor közöttiek voltak. Szülői és kortárs kapcsolati minőséget, pszichológiai distresszt és a diabétesszel öszszefüggő egészséget mértek. A TK és TT rosszabb kapcsolatokkal és nagyobb distresszel társult az egészséges és a beteg kamaszok közt egyaránt. A TK romló diabéteszes egészséget, valamint több, és idővel növekvő számú depresszív tünetet jelzett előre, amely tünetek részben magyarázták a TK és a romló öngondoskodás közti kapcsolatot. A TT összefüggésben volt a szülőkkel és a barátokkal kapcsolatos problémákkal, az idővel növekvő haraggal és csekély öngondoskodással. A K pozitív kapcsolatot mutatott - nem várt módon - az egészséggel: kevesebb volt a depressziós tünet, a harag, valamint az öngondoskodás, és a metabolikus kontrol javulását tapasztalták.

Helgeson (1990) kardiológiai betegek körében végzett vizsgálatának eredményei szerint a TT az "A-típusú" személyiséggel mutatott szoros kapcsolatot. Ezek a személyek a jobb társas támogatással rendelkező (T) személyekkel szemben az infarktus első jeleinek megjelenését követően csak hoszszabb idő elteltével kértek orvosi segítséget. Az infarktus kimenetelével kapcsolatos adatok világosan mutatják, hogy a TT személyeknél a betegség súlyosabb lefolyású volt. A betegségek kimenetelét a nemi szerep sajátosságain túl a házastárs hozzáállása jelentős mértékben módosította.

Amennyiben a TT beteg házastársa is krónikus betegségben szenvedett, a kimenetel tovább romlott. A házastárs betegségének tünetekre gyakorolt negatív hatása a krónikus betegségben szenvedő TK betegek esetén is megjelent. Az életmód-változtatás területén adott instrukciók az esetek többségében hatástalannak bizonyultak: sem a TT, sem a TK betegek nem korlátozták aktivitásukat a kórházból történő elbocsátás utáni 3 hónapban. A változtatás szándéka nélkül, a korábban megszokott mederben próbálták 
tartani az életvitelüket. A TT házastársak a partnerük betegségére bagatellizálással, tagadással, bizonyos mértékben közönnyel reagáltak: kevesebbet segítettek a házimunkában, együttmúködési hajlandóságuk visszafogott volt. Ez az ellenséges és érzelmileg visszahúzódó megküzdési stílus nemcsak a beteg számára, hanem az egyén számára sem adaptív megoldás. A TK házastársak azonban a párjuk betegségére túlvédéssel, a házimunkák és a családi feladatok nagy részének átvételével reagáltak (Helgeson, 1993).

Egy másik tanulmányban a TK betegek az első kardiológiai eseményt követó 4 hónapos időszakban hangulatzavarokra és szorongásra panaszkodtak, továbbá a betegség maradványtüneteit is intenzívebben érezték (Fritz, 2000). A társas kapcsolatok és a pszichológiai distressz vizsgálata során a T és a TT betegek több eredmény mentén is eltértek egymástól: a T beteget magas önbecsülés és csökkent pszichológiai distressz, míg a TT-t negatív kapcsolatok, alacsony önbecsülés és fokozott pszichológiai distressz jellemezte. A vizsgálatban a K és a TK is különválik: a K beteg ad és el is fogad társas támogatást, egyfajta egészséges, másokra irányuló fókusz jellemzi, ezzel ellentétben a TK egyén támogatással látja el a körülötte élőket, de ő maga nem feltétlenül érzékel elérhető támogatást önmaga számára, sőt, negatív kapcsolatai vannak, és az egészségmagatartása sem megfelelő (Helgeson \& Fritz, 1999).

A depresszió és a túlzott kapcsolat-, és tevékenységorientáltság kapcsolata az eddig felsoroltakon kívül még számos tanulmányban igazolódott. Egészséges egyetemi hallgatók körében végzett vizsgálatban (Danoff-Burg, Mosher, \& Grant, 2006; Mosher \& Danoff-Burg, 2008) a distressz a TK és a TT személyeknél egészségkárosító magatartással (kontrollálatlan evés, túl vakmerő autóvezetés, szerhasználat) is párosult. A TK, valamint a TT, továbbá az általános negatív affektivitás és a depresszió kapcsolata egészséges személyeknél is megmutatkozott (Aubé, 2008; Bruch, 2002; Hirokawa \& Dohi, 2007; Jin, Yperen, Sanderman, \& Hagedoorn, 2010).

\section{A nemi szerephez kapcsolódó személyiségvonások szélsőséges formái és a társas kapcsolatok}

A betegségre adott nemi reakciók individuális aspektusai mellett, a betegséggel való megküzdés interperszonális kontextusát is célszerú megvizsgálni. Egy beteg társas támogatottsága, a segítségnyújtók elérhető közelsége nagyban hozzájárul a betegség sikeres legyőzéséhez (Pikó, 2010). 


\subsection{Túlzott kapcsolatorientáltság (TK)}

Fritz (2000) korábban már idézett, szívbetegekkel folytatott vizsgálata részben megerősítést ad a társas interakciók és az egészségmagatartás potenciális mediátor szerepéról. A TK, a depresszió és a testi tünetek kapcsolatát részben az magyarázta, hogy a beteg azt érezte, családtagjai és ismerősei nem támogatják az életmód-változtatásra irányuló törekvéseit. Önmagáról alkotott képe kedvezőtlen, alacsony az önbecsülése (Fritz \& Helgeson, 1998). Ennek oka az a kívülre helyezett standard, amihez önértékelését köti. Úgy érzékeli, hogy mások nem ismerik el, és önbecsülését ettől a hibás értékeléstől teszi függővé. A krónikus betegség a TK egyénnek különösen nagy kihívást jelent, mert a beszúkült fizikai státusza veszélyezteti az önbecsülést alátámasztó gondozói szerepét.

A TK személy segítő magatartásának és a motivációjának megértéséhez Helgeson és Fritz (1998) Batson (1995) empátiajutalom, illetve empátiabüntetés elméletét hívja segítségül. Az előbbi szerint az egyén azért segít, hogy jutalmat érjen el (dicséret, büszkeség), az utóbbi szerint pedig azért, hogy elkerülje a büntetést (mások rosszallása, szégyenérzet). Egyik motiváció sem tekinthető önzetlennek, és az önbecsülést sem növeli tartósan, mivel megmarad az a meggyőződése, hogy mások negatívan értékelik (Helgeson, 1994).

A viselkedésük mögött húzódó motiváció mentén maladaptív és adaptív túlzott kapcsolatorientált attitúdöt különít el Basset és Aubé (2013). Az előbbi az én-orientált TK egyén, aki azért áldozza fel önmagát, hogy ezzel megerősítést, pozitív értékelést szerezzen a külvilágtól, célja pedig, hogy ezáltal önmagát jobban érezze. Az utóbbi pedig a másikra orientált TK egyén, a TK önzetlen segító oldala, aki szívesen lemond a saját érdekeiról a mások javára, mert jó véleménye van saját magáról és megbízik másokban. E két különböző motivációs viselkedés személyes és kapcsolati kimenete nagyban eltérő. A saját érdek elé helyezett mások érdeke bizonyos helyzetekben elónyös lehet az egyénnek, a vele kapcsolatban lévő embereknek, és a társadalom egészének is.

A segító magatartás és a másokról történő gondoskodás a jó hangulattal mutatott összefüggést, a támogatás nyújtása csökkent depresszióval járt együtt, de csak olyan egyénekben, akiknél a TK alacsony szinten van (Jin és mtsai, 2010). Esetükben mások igényeinek átmeneti előtérbe helyezése előnyt jelent (Helgeson, Swanson, Ra, Randall, \& Zhao, 2015). A magas TK pontot elérők viszont nem élvezik mások támogatásának az előnyeit, sőt, stresszesebbek a támogatást követően. A probléma lényege, hogy a magas TK egyén a másoknak adott segítségnyújtásban akar kiteljesedni, megfeledkezik önmagáról s ezért nagy árat fizet. Nem gondoskodik a saját én-határainak és önjutalmazó rendszerének kiépítéséről. 
A „gondozás ára” (cost of caring) hipotézis szerint (Kessler, McLeod, \& Wethington, 1985) a támogatásnyújtás distresszt jelenthet, ha a segítséget nyújtó egyén érzelmileg túlságosan belevonódott a támogatás címzettjének nehézségeibe. Ez jellemző a TK egyénre, aki mások problémáit a sajátjaiként kezeli, és felelősnek érzi magát azért, hogy másoknak segítsen. Mások életébe túlzottan beleavatkozik, ami tolakodó, túlzottan gondoskodó magatartásban nyilvánul meg. Rosszul érzi magát, ha valaki visszautasítja a felajánlott segítségét (Aubé, 2008; Fritz \& Helgeson, 1998; Helgeson \& Fritz, 1999). Minél inkább segít másokon, annál inkább elhanyagolja a saját szükségleteit, aminek romló egészségmagatartás a következménye.

Egy kapcsolati stresszor (pl. kritizálás) nagyobb negatív érzelmi hatással van a magas TK egyénekre, mint az alacsonyakra (Nagurney, 2008; Reynolds, Seltman, \& Helgeson, 2006). Ilyen eseményeket a TK egyén visszautasításnak, negatív értékelésnek él meg. E kettó kombinációja vezethet ahhoz, hogy a TK egyén hajlamos az alacsony önbecsülésre és a következményes depresszív tünetekre. Egy reumás nóbetegekkel folytatott tanulmányból (Danoff-Burg, Revenson, Trudeau, \& Paget, 2004) az derül ki, hogy a magas TK vonás kockázati tényező lehet a pszichológiai distresszre, de ha kevés kapcsolati feszültség van a személy környezetében, a támogató közeg ellensúlyozza a fokozott kockázat hátrányos következményeit. Legnagyobb distresszt azok éltek át, akiknél a TK vonás kifejezett volt, s emellett sok kapcsolati feszültséggel éltek.

A TK egyén „kiegyensúlyozatlan” kapcsolatokat tart fenn, amelyekben ő több segítséget ad, mint amennyit kap. A segítség elfogadása ugyanakkor nehézséget jelent számára (Fritz, Helgeson, 1998). A segítségnyújtó szerep betöltését még a betegsége sem korlátozza, mert ezen alapul identitása és önbecsülése. A csalódástól és a visszautasítástól való félelem miatt ritkán kér segítséget. A self-silencing - magyarul „önelhallgattatás” - lényege, hogy az egyén elnyomja az én azon aspektusait, és legátolja azokat a viselkedéseket, amelyek veszélyeztethetnék a másikkal való kapcsolatát (Pántya, Dallos, \& Papp Kovács, 2012).

A reziliencia, mint lelki rugalmasság, lelki edzettség, adaptáció a streszszel és a nehéz helyzetekkel szemben (Sz. Makó \& Kiss, 2015), a „pszichológiai immunrendszer" (Oláh, 2004) része, amely kapcsolati szinten is megjelenhet. A jó (támogató, gondoskodó, szerető) családon kívüli és családon belüli kapcsolatok a rezilienciát befolyásoló tényezők. Mindezek alapján úgy túnik, hogy a TK személy nem igazán támogató és szerető kapcsolatokat tart fenn. Ennek következményeként a TK egyének csökkent rezilienciával rendelkeznek (Bassett \& Aubé, 2013).

A már idézett kardiológiai beteg-házastárs vizsgálatban (Helgeson, 1993) a legnagyobb alkalmazkodási nehézségeket az a páros mutatta, ahol a beteg TT, a házastárs TK személyiségtípusú volt. Ilyen konstellációban kifejezet- 
ten káros kommunikációs dinamikát lehetett megfigyelni, aminek középpontjában a beteg betegsége állt: a TK házastárs folyamatosan emlékeztette a beteget a helyes egészségmagatartásra, míg a TT beteg dacolt ezekkel a javaslatokkal, hogy így fejezze ki autonómiáját. A beteg engedetlensége az orvosi utasítások betartását illetően a társ még intenzívebb erőlködéséhez vezetett, ezzel a beteg egyre dühösebb és dacosabb lett.

Figyelembe véve az eddigieket, a túlzottan kapcsolatorientált (TK) személy attitúdje számos stressz forrása, bár első ránézésre remek kapcsolatai vannak, hiszen a figyelme szinte kizárólag mások felé irányul, mégis sokszor túlgondoskodó és tolakodó. Ebból fakadnak kapcsolati nehézségei és konfliktusai. Azt is várhatnánk, hogy mások viszonozni szeretnék a TK egyén figyelmességét, viszont az ilyen egyén sokszor épp az elvárásaival ellentétesnek érzékeli mások támogató szándékát. Mivel nem panaszkodik, a körülötte élő emberek nem is sejtik, hogy krónikus beteg. Számára olyan, a felépülésüket segító intervenciót kell kidolgozni, amelynek a családi edukáció nélkülözhetetlen része. Továbbá segíteni kell ôt abban, hogy adaptívan tudja kontrollálni a gondozói szerepéból származó aktivitását.

\subsection{Túlzott tevékenységorientáltság (TT)}

Rákos férfiakat vizsgálva az derült ki, hogy azok a betegek, akik magas TT pontszámot értek el, az intenzívebb társas támogatást elutasítóan fogadták, míg az alacsony TT-s betegek a társas támogatásból többet profitáltak (Hoyt \& Stanton, 2011). Úgy tứnhet, hogy a magas TT értékekkel rendelkező személyekben a támogatás növekedése és a segítségnyújtás felajánlása téves vélekedéseket kelt. Úgy gondolják ezek a személyek, hogy aki segítséget fogad el, annak hálát kell mutatnia viszonzásként. Ez a vélt elvárás azzal fenyegetheti oot, hogy a viselkedése mások elvárásainak kontrollja alá kerülhet, amelynek következményeként veszélyben érezheti az autonómiáját.

A TT személy számára az érzelmek kifejezése nehézséget jelent, a sebezhetőség érzését keltheti, ezért nem is teszi ki magát ennek. Stressz idején az érzelmek kimutatásának nehézsége vagy a bizalommal teli légkör hiánya különösen nehéz helyzetbe hozza az ilyen személyt. Helgeson és Lepore (1997) már idézett, prosztatarákos férfiakat vizsgáló tanulmányában a TT betegeknek a rosszabb alkalmazkodás mellett nehézséget okozott még a betegségükről beszélni a családtagjaikkal, barátaikkal, kezelőorvosukkal, és problémát jelentett számukra az intimitás, illetve az érzéseik megosztása a házastársukkal. Hátrányban voltak ezek a személyek, mivel az érzéseik rejtve maradtak mások előtt, így a környezet nem tudott az igényeik szerint segíteni nekik. 
A túlzottan tevékenységorientált személy a saját igényeit helyezi elótérbe, míg a másokéra nem fordít figyelmet (Helgeson \& Fritz, 1999). Nem köteleződik el mások felé, nem ápol jó kapcsolatokat, és másokat negatívan értékel. Így a TT egyén a támogató kapcsolatok kritikus hiányában szenved, sőt elutasítja, énje elleni támadásnak véli a kínálkozó segítséget, mert gyanakvó és bizalmatlan a másik szándékával szemben. Bosszúálló, cinikus és manipulatív, önbecsülése azonban alacsony. Felvetódik a kérdés, hogy vajon miért húvös és ellenséges mások irányában? Talán azért, mert valóban érdektelen számára mások igénye, ezért túnik húvösnek, pedig igazából közömbös? Vagy attól fél, hogy kudarcot vallhat egy kapcsolatban, és ez táplálhatja távolságtartó viselkedését?

A TT személyek számára a „láthatatlan segítség” az előnyös. A rejtett módon érvényesülő támogatás során (lásd részletesen Bolger, Zuckerman, \& Kessler, 2000) a kapott segítséget a címzett nem veszi észre, nem „detektálja”, az mégis segíti ôt a stresszel való megküzdésben. A láthatatlan segítség három fő ismérve: 1 a az „indirekt” törődés (véletlennek álcázott érintések, gyakori „mi” emlegetés); 2. annak háttérbe szorítása, hogy melyikük a támogató, és melyikük a támogatott fél (információkérésre irányuló kérdések); és 3. a probléma fókuszának eltolása a támogatást élvezőról olyan mások felé, akik hasonló cipóben járnak (Overall, Girme, \& Simpson, 2016). Így a megsegített egyén élvezi a támogatás előnyeit anélkül, hogy megfizetné az árát, ami számára a függőség érzését, énképének és önbecsülésének romlását jelentené. A hagyományos férfi nemi szerephez a függetlenség és az instrumentalitás kötődik, és ezek azok a tulajdonságok, amelyeket a nyílt társas támogatás veszélybe sodorhat.

\section{9. Összefoglalás és kitekintés}

A társadalmi nemek (gender) helyzete nem biológiai adottságok eredménye, hanem társadalmi konstrukció (Kimmel, 2000; Kopp, 2010). A nők és férfiak közötti nemi különbségek a családi szerepvállalásban, az érzelmi reakciómódokban, a fizikai felépítésben, a hormonális sajátosságokban, a különböző betegségek előfordulási gyakoriságában, az életvezetésben és az életkilátások tekintetében is megragadhatók. Sandra Bem, a neves szociálpszichológus, a feminitást és a maszkulinitást kevésbé személyes tulajdonságnak tekinti, mint inkább a kulturális diskurzusban megtestesülö, folyamatosan változó attitúdnek és viselkedéskészletnek (Bem, 1993). A kultúra felnagyítja a nemek közti különbséget, és az egyén egyfajta szúrőn, a „nemek szemüvegén" át látja a saját valóságát, és alakítja ki identitását és énképét. 
A kultúra és az egyén szocializációja alakítja ki a nemi szerephez kapcsolódó személyiségvonásokat, amelyek az aktuális társadalmi berendezkedést is tükrözik. Twenge (2009) több mint húsz évet felölelő longitudinális tanulmányában a tevékenységorientáltság (egészséges én-fókusz, individualizmus) egyre növekvő térhódítását találta. Megállapítása szerint a nyugati kultúra egészében egyre inkább önmagát helyezi középpontba. Ezzel ellentétes eredményeket kaptak Japánban (Hirokawa \& Dohi, 2007), ahol a nők és a férfiak is inkább kapcsolatorientált (egészséges más-fókusz, kooperáció), mint tevékenységorientált vonást mutattak. Ennek magyarázata a kultúrában keresendő, mert Japánban - mint sok más kelet-ázsiai közösségi társadalomban - a közösség az érték, és az emberekkel szembeni elvárás az, hogy harmóniában éljenek egymással. A kultúra és a társadalmi berendezkedés így befolyásolja a személyiségvonások jellegét és eloszlását a nemek között. Elképzelhetó, hogy a nemi szerepek változása hosszabb távon az egészségi állapot nemi különbségeinek változásában is megmutatkozik majd.

A nemi szerepekhez kapcsolódó szomatikus és pszichoszomatikus zavarok számos ponton kapcsolódnak a nemmel kapcsolatos énkép affektív és kognitív sajátosságaihoz. A nemi egyenlótlenségek az egészségi állapottal kapcsolatban is tetten érhetők. Az egyik legmarkánsabb ilyen jelenség a férfiak és nők mortalitásának és morbiditásának a különbsége. A pszichoszociális elméletek feltételezik, hogy a szocializáció során kialakult nemi szerepek az egészség- és betegségmagatartáson keresztül befolyásolják a betegségek kialakulását és az életkilátásokat. A biológiai okokon és az egészségmagatartás különbségein túl, tanulmányunkban a nemi szerepek és a nemi szerephez kapcsolódó személyiségvonások jelentőségét kívántuk megvizsgálni. A nemi szerepekből származó eltérések a krónikus betegségekhez történő alkalmazkodás faktoraiban megmutatkoznak. Áttekintettük a megküzdésben és a társas támogatásban megfigyelhető nemi különbségeket, továbbá arra kerestük a választ, hogy a nemi szerephez kapcsolódó személyiségvonások hogyan befolyásolják a krónikus betegek alkalmazkodását. Az összefoglaló tanúsága szerint a fentebb tárgyalt személyiségvonások jobban befolyásolják a betegségekre adott reakciókat, mint a biológiai nem.

A túlzott tevékenységorientáltság a felsőbbrendúség-érzéshez, és sérthetetlenséghez, a férfiak kockázatkereső magatartásához kapcsolódik, a túlzott kapcsolatorientáltság pedig a túlgondoskodó szerephez, ami önmaga elhanyagolása révén szintén növeli a mortalitást. Számos kutatás bizonyította, hogy ezek a személyiségvonások kapcsolatban vannak az egészséggel. Ugyanakkor tényként kezelhetó, hogy a tevékenységorientáltság a pszichológiai jóllét egyik legjobb prediktora, a reziliencia tényezóje. A kapcsolatorientáltság pedig a legjobb előrejelzője a támogató kapcsolatoknak. 
A nemi szerephez kapcsolódó személyiségvonások szélsőséges beállítódásai, a túlzott kapcsolatorientáltság és a túlzott tevékenységorientáltság az egészségkárosító magatartás egyik vezető faktorának tekinthetók.

\section{Irodalomjegyzék}

Addis, M.E., \& Mahalik, J.R. (2003). Men, masculinity, and the context of help seeking. American Psychologist, 58(1), 5-14.

Anderson, N.B. (2004). Encyclopedia of health and behavior. Thousand Oaks, London, New Delhi: Sage Publication

Antal Bacsó, P. (2010). A kihelyezett ágencia, mint üldöző tárgy. Lélekelemzés, 5(2), 22-33.

Arrindell, W.A., Eisemann, M., Richter, J., Oei, T.P., Caballo, V.E., van der Ende, J., et al. (2003). Masculinity-femininity as a national characteristic and its relationship with national agoraphobic fear levels: Fodor's sex role hypothesis revitalized. Behaviour Research and Therapy, 41(7), 795-807.

Arrindell, W.A., Eisemann, M., Oei, T.P.S., Caballo, V.E., Sanavio, E., Sica, C., et al. (2004). Phobic anxiety in 11 nations: part II. Hofstede's dimensions of national cultures predict national-level variations. Personality and Individual Differences, 37(3), 627-643.

Aubé, J. (2008). Balancing concern for other with concern for self: Links between unmitigated communion, communion, and psychological well-being. Journal of Personality, 76(1), 101-133.

Bakan, D. (1966). The duality of human existence. Chicago: Rand McNally

Balog, P., Székely, A., Szabó, G., \& Kopp, M. (2006). A rövidített házastársi stressz skála pszichometriai jellemzői. Mentálhigiéné és Pszichoszomatika, 7(3), 193-202.

Badr, H. (2004). Coping in marital dyads: A contextual perspective on the role of gender and health. Personal Relationships, 11(2), 197-211.

Bartholomew, K., \& Horowitz, L.M. (1991). Attachment styles among young adults: A test of a four-category model. Journal of Personality and Social Psychology, 61(2), 226-244.

Bassett, R.L., \& Aubé, J. (2013). “Please care about me!" or "I am pleased to care about you!": Considering adaptive and maladaptive versions of unmitigated communion. Journal of Psychology and Theology, 41(2), 107-119.

Batson, C.D. (1995). Prosocial motivation: Why do we help others? In A. Tesser (Ed.), Advanced social psychology (333-381). New York: McGraw-Hill

Bem, S.L. (1974). The measurement of psychological androgyny. Journal of Consulting and Clinical Psychology, 42(2), 155-162.

Bem, S.L. (1993). The lenses of gender: Transforming the debate on sexual inequality. New Haven: Yale University Press

Bereczkei, T. (2003). Evolúciós pszichológia. Budapest: Osiris Kiadó

Bodenmann, G., Pihet, S., \& Kayser, K. (2006). The relationship between dyadic coping and marital quality: A 2-year longitudinal study. Journal of Family Psychology, 20(3), 485-493.

Bolger, N., Zuckerman, A., \& Kessler, R.C. (2000). Invisible support and adjustment to stress. Journal of Personality and Social Psychology, 79(6), 953-961.

Bowlby, J. (1969). Disruption of the affectional bonds and its effects on behavior. Canada's Mental Health Supplement, 59, 12-33.

Bruch, M. (2002). The relevance of mitigated and unmitigated agency and communion for depression vulnerabilities and dysphoria. Journal of Counselling Psychology, 49(4), 449-459.

Carver, C.S., \& Scheier, M.F. (2006). Személyiségpszichológia. Budapest: Osiris Kiadó 
Choi, P. (2000). Feminity and the physically active woman. London: Routledge

Courtenay, W.H. (2000). Constructions of masculinity and their influence on men's wellbeing: a theory of gender and health. Social Science Medicine, 50(10), 1385-1401.

Coyne, J.C., \& DeLongis, A. (1986). Going beyond social support: The role of social relationships in adaptation. Journal of Consulting and Clinical Psychology, 54(4), 454-460.

Coyne, J.C., \& Smith, D.A.F. (1994). Couples coping with myocardial infarction: Contextual perspective on patient self-efficacy. Journal of Family Psychology, 8(1), 1-13.

Cserepes, R.E. (2015). Magyar meddő párok pszichológiai jellegzetességeinek vizsgálata egyéni, párkapcsolati és szociokulturális szinteken. PhD-disszertáció. Témavezető: Dr. Bugán Antal. Debreceni Egyetem, Debrecen

Cserepes, R.E., Bugán, A., Körösi, T., Tóth, B., Rösner, S., Strowitzki, T., et al. (2014). Infertility specific quality of life and gender role attitudes in German and Hungarian involuntary childless couples. Geburtshilfe und Frauenheilkunde, 74(11), 1009-1015.

Danoff-Burg, S., Mosher, C.E., \& Grant C.A. (2006). Relations of agentic and communal personality traits to health behavior and substance use among college students. Personality and Individual Differences 40(2), 353-363.

Danoff-Burg, S., \& Revenson, T.A. (2005). Benefit-finding among patients with rheumatoid arthritis: Positive effects on interpersonal relationships. Journal of Behavioral Medicine, 28(1), 91-103.

Danoff-Burg, S., Revenson, T.A., Trudeau, K.J., \& Paget, S.A. (2004). Unmitigated communion, social constraints, and psychological distress among women with rheumatoid arthritis. Journal of Personality, 72(1), 29-46.

Deaux, K., \& LaFrance, M. (1998). Gender. In D.T. Gilbert, S.T. Fiske, \& G. Lindzey (Eds.), The Handbook of Social Psychology. Boston: Mcgraw Hill

Doyal, L. (2001). Sex, gender and health: the need for a new approach. BMJ, 323(7320), 1061-1063.

Fritz, H.L. (2000). Gender-linked personality traits predict mental health and functional status following a first coronary event. Health Psychology, 19(5), 420-428.

Fritz, H.L., \& Helgeson, V.S. (1998). Distinctions of unmitigated communion from communion: Self-neglect and overinvolvement with others. Journal of Personality and Social Psychology, 75(1), 121-140.

Ghaed, S.G., \& Gallo, L.C. (2006). Distinctions among agency, communion, and unmitigated agency and communion according to the interpersonal circumplex, five-actor model, and social-emotional correlates. Journal of Personality Assessment, 86(1), 77-88.

Goldzweig, G., Hubert, A., Walach, N., Brenner, B., Perry, S., Andritsch, E., et al. (2009). Gender and psychological distress among middle- and older-aged colorectal cancer patients and their spouses: an unexpected outcome. Critical Reviews in Oncology/ Hematology, 70(19), 71-82.

Hagedoorn, M., Sanderman, R., Bolks, H. N., Tuinstra, J., \& Coyne, J. C. (2008). Distress in couples coping with cancer: A meta-analysis and critical review of role and gender effects. Psychological Bulletin, 134(1), 1-30.

Helgeson, V.S. (1990). The role of masculinity as a prognostic predictor of heart attack severity. Sex Roles, 22(11-12), 755-774.

Helgeson, V.S. (1993). Implication of agency and communion for patient and spouse adjustment to a first coronary event. Journal of Personality and Social Psychology, 64(5), 807-816.

Helgeson, V.S. (1994). Relation of agency and communion to well-being: Evidence and potential explanations. Psychological Bulletin, 116(3), 412-428. 
Helgeson, V.S. (2003a). Gender-related traits and health. In J. Suls, \& K.A. Wallston (Eds.), Social psychological foundations of health and illness (367-394). Oxford: Blackwell Publishing

Helgeson, V.S. (2003b). Unmitigated communion and adjustment to breast cancer: Association and explanations. Journal of Applied Social Psychology, 33(8), 1643-1661.

Helgeson, V.S. (2012). The psychology of gender. New Jersey: Pearson Education Inc.

Helgeson, V.S., \& Fritz, H.L. (1998). A theory of unmitigated communion. Personality and Social Psychology Review, 2(3), 173-183.

Helgeson, V.S., \& Fritz, H.L. (1999). Unmitigated agency and unmitigated communion: Distinctions from agency and communion. Journal of Research in Personality, 33(2), 131158.

Helgeson, V.S., \& Fritz, H.L. (2000). The implication of unmitigated agency and unmitigated communion for domains of problem behavior. Journal of Personality, 68(6), 1031-1057.

Helgeson, V.S., \& Lepore, S.J. (1997). Men's adjustment to prostate cancer: The role of agency and unmitigated agency. Sex Roles, 37(3-4), 251-267.

Helgeson, V.S., \& Lepore, S.J. (2004). Quality of life following prostate cancer: The role of agency and unmitigated agency. Journal of Applied Psychology, 34(12), 2559-2585.

Helgeson, V.S., \& Palladino, D.K. (2011). Agentic and communal traits and health: adolescents with and without diabetes. Personality and Social Psychology Bulletin, 20(10) 1-14.

Helgeson, V.S., Swanson, J., Ra, O., Randall, H., \& Zhao Y. (2015): Links between unmitigated communion, interpersonal behaviors and well-being: A daily diary approach. Journal of Research in Personality, 57, 53-60.

Hinnen, C., Hagedoorn, M., Ranchor, A.V., \& Sanderman, R. (2008). Relationship satisfaction in women: a longitudinal case-control study about the role of breast cancer, personal assertiveness, and partners' relationship-focused coping. British Journal of Health Psychology, 13(4), 737-754.

Hirokawa, K., \& Dohi, I. (2007). Agency and communion related to mental health in Japanese young adults. Sex Roles, 56(7-8), 517-524.

Hoyt, M.A., \& Stanton A.L. (2011). Unmitigated agency, social support, and psychological adjustment in men with cancer. Journal of Personality, 79(2), 259-276.

Hunt, K., Lewars, H., Emslie, C., \& Batty, G.D. (2007). Decreased risk of death from coronary heart disease amongst men with higher 'femininity' scores: a general population cohort study. International Journal of Epidemiology, 36(3), 612-620.

Hwang, V.S., \& Danoff-Burg, S. (2010). Gender Issues in the Diagnosis and Treatment of Chronic Illness. In J.C. Chrisler, \& D.R. McCreary (Eds.), Handbook of Gender Research in Psychology. Volume 2: Gender Research in Social and Applied Psychology (541-560). New York: Springer

Jin, L., Yperen, N., Sanderman, R., \& Hagedoorn, M. (2010). Depressive symptoms and unmitigated communion in support providers. European Journal of Personality, 24(1), 56-70.

Kaplan, R.M., Anderson, J.P., \& Wingard, D.L. (1991) Gender differences in health-related quality of life. Health Psychology, 10(2), 86-93.

Kessler, R.C., McLeod, J.D., \& Wethington, E. (1985). The cost of caring: A perspective on the relationship between sex and psychological distress. In I.G. Sarason, \& B.R. Sarason (Eds.), Social support: Theory, research and application (491-506). Dordrecht: Nijhoff

Kiecolt-Glaser, J.K., \& Newton, T. (2001). Marriage and health: His and hers. Psychological Bulletin, 127(4), 472-503.

Kimmel, M.S. (2000). The gendered society. Oxford: Oxford University Press

Kopp, M. (2007). A kelet-közép-európai egészségparadoxon. In Kállai J., Varga J., Oláh A. (Eds.), Egészségpszichológia a gyakorlatban (51-64). Budapest: Medicina 
Kopp, M. (2010). A gender-kutatások népegészségügyi és demográfiai jelentősége. Mentálhigiéné és Pszichoszomatika, 11(4), 243-254.

Láng, A. (2009). Érzelemszabályozás és kötődés összefüggései normatív mintában. Alkalmazott Pszichológia, 11(3-4), 5-17.

Lee, C. (2010). Gender, health, and health behaviors. In J.C. Chrisler, \& D.R. McCreary (Eds.), Handbook of Gender Research in Psychology. Volume 2: Gender Research in Social and Applied Psychology (471-493). New York: Springer

Lippa, R.A., Martin, L.R., \& Friedman, H.S. (2000). Gender-related individual differences and mortality in the Terman longitudinal study: Is masculinity hazardous to your health? Personality and Social Psychology Bulletin, 26(12), 1560-1570.

Luy, M. (2002). Warum Frauen länger leben - Erkenntnisse aus einem Vergleich von Kloster- und Allgemeinbevölkerung. Materialien zur Bevölkerungswissenschaft 106. Wiesbaden: Bundesinstitut für Bevölkerungsforschung

Manne, S.L., Norton, T.R., Ostroff, J.S., Winkel, G., Fox, K., \& Grana, G. (2007). Protective buffering and psychological distress among couples coping with breast cancer: The moderating role of relationship satisfaction. Journal of Family Psychology, 21(3), 380-388.

Matarazzo, J.D. (1984). Behavioral health: A 1990 challenge for the health sciences professions. In J.D. Matarazzo, N.E. Millner, S.M. Weis, \& J.A. Herd (Eds.), Behavioral health: A handbook of health enhancement and disease prevention (3-40). New York: John Wiley

Mosher, C.E., \& Danoff-Burg, S. (2008). Agentic and communal personality traits: Relations to disordered eating behavior, body shape concern, and depressive symptoms. Eating Behaviors, 9(4), 497-500.

Nagurney, A.J. (2008). The effect of Unmitigated Communion and life events among women with fibromyalgia syndrome. Journal of Health Psychology 13(4), 520-528.

Oláh, A. (2004). Mi a pozitívuma a pozitív pszichológiának? Iskolakultúra, 2004/11, 39-47.

Orth-Gomér, K. (2015). Psychosocial risk factors for coronary heart disease in women: The Stockholm Studies of Women's Heart. In K. Orth-Gomér, N. Schneidermann, V. Vaccarino, \& H-C. Deter (Eds.), Psychosocial stress and cardiovascular disease in women (41-61). New York: Springer

Orth-Gomér, K., Wamala, S.P., Horsten, M., Schenk-Gustafsson, K., Schneidermann, N., \& Mittleman, M.A. (2000). Marital stress worsens prognosis in women with coronary heart disease: The Stockholm Female Coronary Risk Study. JAMA, 284(23), 3008-3014.

Overall, N.C., Girme, Y.U., \& Simpson J.A. (2016). The power of diagnostic situations: how support and conflict can foster growth and security. In C.R. Knee, \& H.T. Reis (Eds.), Positive approaches to optimal relationship development (148-170). Cambridge: Cambridge University Press

Pántya, J., Dallos, A., \& Papp Kovács, J. (2012). A nemi alapú elutasítás iránti érzékenység és a férfiakkal szembeni ellenséges hiedelmek hatása az elutasítást követő helyzetértelmezésre és a megbocsátási szándékra. Alkalmazott Pszichológia, 14(2), 21-42.

Pikó, B. (2010). Védőfaktorok nyomában. Pozitív fordulat a magatartáskutatásokban? In Pikó Bettina (Eds.), Védőfaktorok nyomában. A káros szenvedélyek megelőzése és egészségfejlesztés serdülókorban (11-22). Budapest: L'Harmattan Kiadó

Piro, M., Zeldow, P.B., Knight, S.J., Mytko, J.J., \& Gradishar, W.J. (2001). The Relationship Between Agentic and Communal Personality Traits and Psychosocial Adjustment to Breast Cancer. Journal of Clinical Psychology in Medical Settings, 8(4), 263-271.

Pongrácz, T. (2005): Nemi szerepek társadalmi megítélése. Egy nemzetközi összehasonlító vizsgálat tapasztalatai. In I. Nagy, T. Pongrácz, \& I. Gy. Tóth (Szerk.), Szerepváltozások. Jelentés a nők és férfiak helyzetéről (73-86). Budapest: TÁRKI, Ifjúsági, Családügyi, Szociális és Esélyegyenlőségi Minisztérium 
Reynolds, K.A., Seltman, H., \& Helgeson, V.S. (2006). Impact of Interpersonal Conflict on Individuals High in Unmitigated Communion. Journal of Applied Social Psychology, 36(7), 1595-1616.

Rottmann, N., Hansen, D.G., Larsen, P.V., Nicolaisen, A., Flyger, H., Johansen, C., et al. (2015). Dyadic coping within couples dealing with breast cancer: A longitudinal, population-based study. Health Psychology, 34(5), 486-495.

Schokker, M.C., Stuive, I., Bouma, J., Keers, J.C., Links, T.P., Wolffenbuttel, B.H., et al. (2010). Support behavior and relationship satisfaction in couples dealing with diabetes: main and moderating effects. Journal of Family Psychology, 24(59), 578-586.

Sieverding, M. (2005). Geschlecht und Gesundheit. In R. Schwarzer (Ed.), Gesundheitspsychologie (55-70). Göttingen: Hogrefe

Sieverding, M. (2009). Gender. In von J. Bengel, \& M. Jerusalem (Eds.), Handbuch der Gesundheitspsychologie und Medizinischen Psychologie (130-139). Göttingen: Hogrefe

Smith, T.W., \& Gallo, L.C. (2001). Personality traits as risk factors for physical illness. In A. Baum, T. Revenson, \& J.E. Singer (Eds.), Handbook of health psychology (139-172). Hillsdale: Erlbaum

Spence, J.T. (1984). Masculinity, feminity, and gender-related traits: A conceptual analysis and critique of current research. Progress in Experimental Personality Research, 13, 1-97.

Spence, J.T., Helmreich, R.L., \& Holahan, C.K. (1979). Negative and positive components of psychological masculinity and feminity and their relatonship to self-reports of neurotic and acting out behaviors. Journal of Personality and Social Psychology, 37(10), 1673-1682.

Spence, J.T., Helmreich, R.L., \& Stapp, J. (1974). The Personal Attributes Questionnaire: A measure of sex-role stereotypes and masculinity-feminity. JSAS: Catalog of Selected Documents in Psychology, 4, 43-44.

Stake, J.E., \& Eisele, H. (2010). Gender and Personality. In J.C. Chrisler, \& D.R. McCreary (Eds.), Handbook of Gender Research in Psychology. Volume 2: Gender Research in Social and Applied Psychology (19-40). New York: Springer

Stanton, A.L., Collins, C.A., \& Sworowski, L.A. (2001). Adjustment to chronic illness: Theory and research. In A. Baum, T.A. Revenson, \& J.E. Singer (Eds.) Handbook of health psychology (387-403). Mahwah: Lawrence Erlbaum

Stanton, A.L., \& Revenson, T.A. (2007). Adjustment to chronic disease: Progress and promise in research. In H.S. Friedman, \& R.C. Silver (Eds.), Foundation of health psychology (203233). New York: Oxford University Press

Susánszky, A., Susánszky, É., \& Kopp, M. (2009). Mitől szoronganak a magyar férfiak? A férfi nemi szerep stresszjellegzetességei. LAM, 19(6-7), 431-435.

Szántó, Zs., \& Susánszky, É. (2010). Gender és egészség - Szakirodalmi áttekintés. Mentálhigiéné és Pszichoszomatika, 11(4), 255-276.

Sz. Makó, H., \& Kiss, E. (2015). A múvi abortusz nők mentális egészségére gyakorolt rövid és hosszú távú hatása a reziliencia, coping és neuroticizmus jellemzők összefüggéseiben. Alkalmazott Pszichológia, 17(1), 93-109.

Taylor, S.E. (2007). Social support. In H.S. Friedman, \& R. C. Silver (Eds.), Foundation of health psychology (145-171). New York: Oxford University Press

Taylor, S.E., Klein, L.C., Lewis, B.P., Gruenewald, T.L., Gurung, R.A., \& Updegraff, J.A. (2000). Biobehavioral responses to stress in females: tend-and-befriend, not fight-orflight. Psychological Review, 107(3), 411-429.

Todorowa, I. (2011): Two decades on social change in Central and Eastern Europe: Implications for health. In H.S. Friedman (Ed.), The Oxford handbook of health psychology (824-847). New York: OUP 
Traa, M.J., De Vries, J., Bodenmann, G., \& Den Oudsten, B.L. (2015). Dyadic coping and relationship functioning in couples coping with cancer: a systematic review. British Journal of Health Psychology, 20(1), 85-114.

Trudeau, K.J., Danoff-Burg, S., Revenson, T., \& Paget, S. (2003). Agency and communion in people with rheumatoid arthritis. Sex Roles, 49(7-8), 303-311.

Twenge, J.M. (2009). Status and gender: The paradox of progress in an age of narcissism. Sex Roles, 61(5), 338-340.

Vaccarino, V. (2015). Psychosocial risk factors in women: Special reference to depression and posttraumatic stress disorder. In K. Orth-Gomér, N. Schneidermann, V. Vaccarino, \& H-C. Deter (Eds.), Psychosocial stress and cardiovascular disease in women (41-61). New York: Springer

Verhofstadt, L.L., Buysse, A., \& Ickes, W. (2007). Social support in couples: An examination of gender differences using self-report and observational methods. Sex Roles, 57(3), 267-282.

Weiten, W., Dunn, D.S., \& Hammer, E.Y. (2015). Psychology applied to modern life. Adjustment in the 21th century (11 ${ }^{\text {th }}$ ed.) Stamford: Cengage Learning

Wiggins, J.S., \& Trappnell, P.D. (1996). A dyadic-interactional perspective on the five-factor model. In J.S. Wiggins (Eds.), The five-factor model of personality: Theoretical perspective (88-162). New York: The Guilford Press

Zwicker, A., \& DeLongis, A. (2010): Gender, Stress, and Coping. In J.C. Chrisler, \& D.R. McCreary (Eds.), Handbook of Gender Research in Psychology. Volume 2: Gender Research in Social and Applied Psychology (495-515). New York: Springer

\section{Szerzói munkamegosztás}

Mindhárom szerző részt vett a tanulmány megszövegezésében a szerzői sorrendnek megfelelő arányban.

\section{Nyilatkozat érdekütközésról}

A szerzők ezúton kijelentik, hogy esetükben nem állnak fenn érdekütközések.

\section{The context of the gender-related factors in the development and progress of chronic illnesses}

$$
\text { NAGY, TÜNDE - TIRINGER, ISTVÁN - KÁLLAI, JÁNOS }
$$

The purpose of this article is to review the results of the research on a central concept of gender medicine dealing with the relationship between gender roles and health, and the effect of the gender-related traits to the adjustment to chronic illnesses. Research on coping with chronic illness and social support in the context of gender is also summarized. 
The linking of gender roles and health is influenced by health behaviors directly, and socializing processes indirectly, the later through the effect exerted on the self-concept. In the domains of adjustment to chronic illness gender-related traits often account for sex differences in outcomes and show stronger relations to outcomes compared to participants' sex. Agency, communion and its unmitigated counterparts have different effects on health behavior, social support and adjustment to chronic illnesses. Whereas agency is associated with positive health behaviors, and communion is associated with positive relationship outcomes, its unmitigated counterparts are related to physical and mental adjustment difficulties, poor health behavior, and predict increased distress following the illness and negative social interactions.

Keywords: gender roles, gender-related traits, health, adjustment to chronic illness 